\title{
Steroidogenesis in bovine granulosa cells: the effect of short-term changes in dietary intake
}

\author{
D. G. Armstrong ${ }^{1}$, J. G. Gong ${ }^{1}$, J. O. Gardner ${ }^{1}$, G. Baxter ${ }^{1}$, \\ C. O. Hogg ${ }^{1}$ and R. Webb² \\ ${ }^{1}$ Division of Integrative Biology, Roslin Institute (Edinburgh), Roslin, Midlothian EH25 9PS, \\ UK; and ${ }^{2}$ Division of Agriculture and Horticulture, School of Biosciences, University of \\ Nottingham, Sutton Bonington Campus, Loughborough LE12 5RD, UK
}

The nutritional status of a cow is a key factor in the regulation of both follicle growth and oocyte quality. In this study, the effect of diets designed to increase circulating insulin and insulin-like growth factor I (IGF-I) concentrations on steroid production by granulosa cells in vitro was examined to analyse the mechanisms through which these changes occur. Hereford $\times$ Friesian heifers $(n=24)$ were offered maintenance or twice maintenance diets during the experimental period (17 days). Circulating concentrations of FSH did not differ between the two dietary groups, whereas insulin and IGF-I concentrations showed significant diet $\times$ day of oestrous cycle interactions. Ovaries were collected on day 3 of the first follicle wave after synchronization of oestrus. Granulosa cells were isolated from small (1-4 mm) and medium-sized (4-8 mm) follicles and cultured in the presence of long R3-IGF-I or bFSH or both. After 4 days in culture, granulosa cells isolated from small follicles, but not medium-sized follicles, collected from cattle offered the twice maintenance diet secreted significantly higher $(P<0.05)$ amounts of oestradiol compared with granulosa cells collected from cattle offered the maintenance diet. The effect was apparent in either the presence or absence of FSH and long R3-IGF-I. This nutritional effect on aromatase activity in granulosa cells was not apparent after day 6 of culture. There was no effect of diet on progesterone production by granulosa cells after 4 or 6 days of culture. These results support the hypothesis that dietary-induced changes in circulating insulin and IGF-I concentrations have a direct effect on the steroidogenic potential of bovine granulosa cells from small follicles. The dietary-induced increases in aromatase activity in small follicles combined with the increased concentration of metabolic hormones are possible mechanisms through which short-term changes in nutrition may affect follicle dynamics.

\section{Introduction}

Nutritional status is a major factor controlling fertility in cattle and the direct effects of nutrition on ovarian function have been well documented (Robinson, 1990; O'Callaghan and Boland, 1999; Robinson et al., 1999; Boland et al., 2001). Specific examples of the influence of dietary intake on ovarian function are the correlations between the diameters of preovulatory follicles and weight loss in beef cattle (Rhodes et al., 1995), and between negative energy balance and follicle growth in postpartum dairy cattle (Beam and Butler, 1999), and the effects of diet on developmental competence of oocytes in heifers (Sinclair et al., 2000; Armstrong et al., 2001).

Although the effects of short-term changes in nutrition on bovine ovarian function have been described, the precise mechanisms involved in regulation of follicle growth are not understood. Recent studies have indicated that shortterm changes in nutrition regulate follicle recruitment without affecting circulating concentrations of $\mathrm{FSH}$ (Gutierrez et al., 1997a). Circulating insulin concentrations

Email: david.armstrong@bbsrc.ac.uk were positively correlated with dietary energy and it was proposed that this hormone is a key factor in mediating the effects of dietary intake on ovarian function. Supporting this contention are the observations that bovine granulosa cells in culture are dependent on the presence of physiological concentrations of insulin (Holtorf et al., 1989; Gutierrez et al., 1997b; Glister et al., 2001) and that the infusion of insulin into beef heifers resulted in an increase in the diameter of the dominant follicle (Simpson et al., 1994).

Subsequent studies have shown that diets designed specifically to increase circulating insulin and insulin-like growth factor I (IGF-I) concentrations affect the ovarian IGF system directly (Armstrong et al., 2001). In particular, mRNAs encoding IGF-binding protein 2 (IGFBP-2) in granulosa cells and IGFBP-4 in theca cells from small follicles were reduced in cattle offered a high energy diet compared with those offered a lower energy diet. Armstrong et al. (2001) hypothesized that a decrease in the steady state expression of mRNAs encoding IGFBP-2 and -4 would increase the bioavailability of IGF in small follicles and, thereby, increase their response to $\mathrm{FSH}$, resulting in the increased growth rate of small follicles.

As a consequence of these nutritionally induced changes 
Table 1. Chemical analysis of the cattle feed (1663 harvest feed nuts) used for maintenance and twice maintenance diets of heifers

\begin{tabular}{lcc}
\hline & Hay & Concentrate \\
\hline Dry matter $\left(\mathrm{g} \mathrm{kg}^{-1}\right)$ & 913 & 863 \\
Metabolizable energy & & \\
$\quad(M J$ per kg dry matter) & 8.3 & 10.9 \\
Crude protein (g per kg dry matter) & 83 & 190 \\
Organic matter & 942 & 927 \\
Acid detergent fibre & 288 & 148 \\
Neutral detergent fibre & 664 & 220 \\
\hline
\end{tabular}

in the ovarian IGF system, we predicted that granulosa cells isolated from small follicles collected from the ovaries of cattle at a high plane of nutrition would produce more oestradiol in vitro than granulosa cells collected from cattle at a lower plane of nutrition. Therefore, this study was designed to analyse the effects of short-term changes in dietary intake on steroidogenesis in bovine granulosa cells in vitro.

\section{Materials and Methods}

\section{Materials}

Medium 199, McCoys 5A modified medium, Hepes, amphotericin, L-glutamine, Dulbecco's phosphate-buffered saline without calcium and magnesium (DPBS-), McCoy's 5 a medium with sodium bicarbonate, PenStrep solution containing 10000 iu penicillin and $10 \mathrm{mg}$ streptomycin per $\mathrm{ml}$, bovine serum albumin (BSA), tissue culture grade transferrin, selenium, bovine insulin, neutral red, trypsin, testosterone and trypan blue were all purchased from Sigma Aldrich Co. Ltd (Poole). Bovine FSH (USDA-bFSH-I-2; bioactivity potency 854 iu $\mathrm{mg}^{-1}$ ) was generously donated by the US Department of Agriculture. Human recombinant IGF-I and the IGF-I analogue long R3-IGF-I (LR3-IGF-I, which has a reduced affinity to IGFBPs), were acquired from Gropep Pty Ltd (Adelaide).

\section{Dietary treatments and experimental design}

Twenty-four cattle were selected from a herd of 2-3year-old Hereford $\times$ Friesian heifers, with an average body weight of $449.4 \pm 31.0 \mathrm{~kg}$ (mean $\pm \mathrm{SD} ; n=32$ ) and body condition score ranging from 1.75 to 2.50 (on a scale of 1-5). The animals were divided randomly into three experimental groups $(n=8)$ and kept individually in pens with wood shavings as bedding material. Within each experimental group, heifers $(n=4)$ were allocated randomly into two treatment groups and fed either a maintenance or twice maintenance diet, offered as two meals per day at 09:00 $\mathrm{h}$ and $16: 30 \mathrm{~h}$.

The compositions of the two diets (Table 1) were calculated according to AFRC (1993), and consisted of $2 \mathrm{~kg}$ hay per day and either $2.5 \mathrm{~kg}$ concentrate per day (maintenance group) or $6.5 \mathrm{~kg}$ concentrate per day (twice maintenance group).
For 1 week before the start of the experiment the animals were adapted to their respective diets. Controlled feeding (Fig. 1) began on the day of insertion of a controlled intravaginal drug-releasing device (CIDR; InterAg, Hamilton). The oestrous cycles of the heifers were synchronized by a $\mathrm{PGF}_{2 \alpha}$ (Estrumate; Coopers Animal Health Ltd, Crewe) injection 2 days before CIDR removal (day 10) and ovulation was induced by a GnRH agonist (Buserelin; Hoechst, Hounslow) injection on day 12. Heifers were killed on day 17 (day 3 of the first follicle wave) at a local abattoir. Blood sampling $(10 \mathrm{ml})$ and ultrasonography were performed daily after feeding between 09:00 $\mathrm{h}$ and 11:00 h.

\section{Isolation of granulosa cells}

After the heifers were killed, the ovaries were placed immediately in collection medium (medium 199, with $20 \mathrm{mmol}$ Hepes $\mathrm{I}^{-1}$, $100 \mathrm{iu}$ penicillin $\mathrm{ml}^{-1}, 0.1 \mathrm{mg}$ streptomycin $\mathrm{ml}^{-1}$ and $\left.0.1 \%(\mathrm{w} / \mathrm{v}) \mathrm{BSA}\right)$ at $37^{\circ} \mathrm{C}$, and transported to the laboratory. The ovaries were trimmed, washed briefly in $70 \%(\mathrm{v} / \mathrm{v})$ ethanol and maintained in collection medium (at $37^{\circ} \mathrm{C}$ ) until dissection. The follicles were blunt-dissected and classified according to external diameter into small $(<4 \mathrm{~mm})$ and medium-sized $(4-8 \mathrm{~mm})$ follicles. Granulosa cells were isolated from each group of follicles as described by Gutierrez et al. (1997b) and suspended in culture medium consisting of McCoy 5A modified medium supplemented with 1\% (v/v) PenStrep solution, $10 \mathrm{ng}$ bovine insulin $\mathrm{ml}^{-1}$, either 0 or $10 \mathrm{ng}$ LR3IGF-I $\mathrm{ml}^{-1}, 3$ mmol glutamine $\mathrm{I}^{-1}, 20 \mathrm{mmol}$ Hepes $\mathrm{I}^{-1}, 5 \mathrm{mg}$ apo-transferrin $\mathrm{ml}^{-1}, 4 \mathrm{ng}$ sodium selenite $\mathrm{ml}^{-1}, 0.1 \%(\mathrm{w} / \mathrm{v})$ BSA and $10^{-7}$ mol testosterone $\mathrm{I}^{-1}$. The number of cells was counted using a haemocytometer and viability estimates measured after trypan blue dye exclusion ranged from 10 to $25 \%$.

\section{Cell culture}

Three cultures were performed. Each culture was performed using granulosa cells isolated from eight heifers. Within each culture, ovaries were grouped according to whether they were collected from heifers offered the maintenance or twice maintenance diet and within both of these groups follicles were subdivided further according to follicle size before pooling and isolation of granulosa cells. Cells $\left(5.0-7.5 \times 10^{4}\right.$ per $50 \mu \mathrm{l}$ culture medium) were seeded into individual wells in 96-well culture plates (Nunclon; Life Technologies, Paisley) according to the procedure described by Gutierrez et al. (1997b) in a final volume of $250 \mu \mathrm{l}$ culture medium. On each of days 2 and 4 of culture, $80 \%(200 \mu \mathrm{l})$ of the culture medium was removed (taking care not to disturb the loosely adherent cells) and replaced with fresh medium. After day 6 of culture, the number of granulosa cells was estimated by the uptake of neutral red, as described by Campbell et al. (1996). The granulosa cell conditioned culture medium was 
stored at $-20^{\circ} \mathrm{C}$ until it was assayed for oestrogen and progesterone.

\section{Radioimmunoassays}

Oestradiol and progesterone concentrations in unextracted culture medium were measured by radioimmunoassay (Corrie et al., 1981; Webb et al., 1985), validated previously for unextracted culture medium (Gong et al., 1994). Steroid measurements during days $2-4$ and $4-6$ of culture were adjusted for carryover from days $0-2$ and 2-4 of culture, respectively. Plasma IGF-I concentration was measured by radioimmunoassay after acid gel filtration to remove IGFBPs (Gutierrez et al., 1997c), using a rabbit polyclonal antibody raised against human recombinant IGF-I (Armstrong et al., 1990). The sensitivity of the assay was 22 pg per assay tube and the inter- and intra-assay coefficients of variation were 13 and $8 \%$, respectively. FSH concentrations were measured by radioimmunoassay as described by Gong et al. (1995). The sensitivity of the assay was $0.1 \mathrm{ng} \mathrm{ml}^{-1}$ and the intra-assay coefficient of variation was $1.2 \%$. Insulin concentrations were measured by radioimmunoassay (Gong et al., 1993). The sensitivity of the assay was $0.04 \mathrm{ng} \mathrm{ml}^{-1}$ and the intra-assay coefficient of variation was $7.4 \%$.

\section{Follicle dynamics}

The pattern of follicular development was examined daily from day 6 to day 16 of the experimental period, using an ultrasound scanner (Aloka Echo Camera SSD-210 DX II) fitted with a 7.5 MHz linear array transrectal probe (Aloka Co. Ltd). Follicles were classified according to their diameter as small (2-4 mm) or medium-sized (4-8 $\mathrm{mm})$.

\section{Statistical analyses}

Data relating to plasma insulin, IGF-I, FSH, follicular growth, animal weight and body condition score were analysed using repeated measures (split-plot) ANOVA (Genstat 5, Version 4.21; Lawes Agricultural Trust, Rothamstead, 1993). The analysis allowed for variation due to treatment (diet), animal within treatment, day of experiment and interaction of day and treatment. The significance of the effect of level of feeding was tested using the animal within treatment as an error term.

Three separate cell culture experiments were performed. Each experiment used eight cows, four of which were fed the twice maintenance diet and four the maintenance diet. Within each experiment, granulosa cells were pooled according to size and the effect of treatments within diets was measured in quadruplicate. Effects of days of culture, diet and hormone treatments (LR3-IGF-I and FSH) on steroid production were analysed by split-plot ANOVA allowing for variation due to culture and different pools of cells (random effects). Oestradiol and progesterone production were analysed after logarithmic transformation to correct for heterogeneity of variance. Data from the cell culture experiments are presented as overall means of the three separate
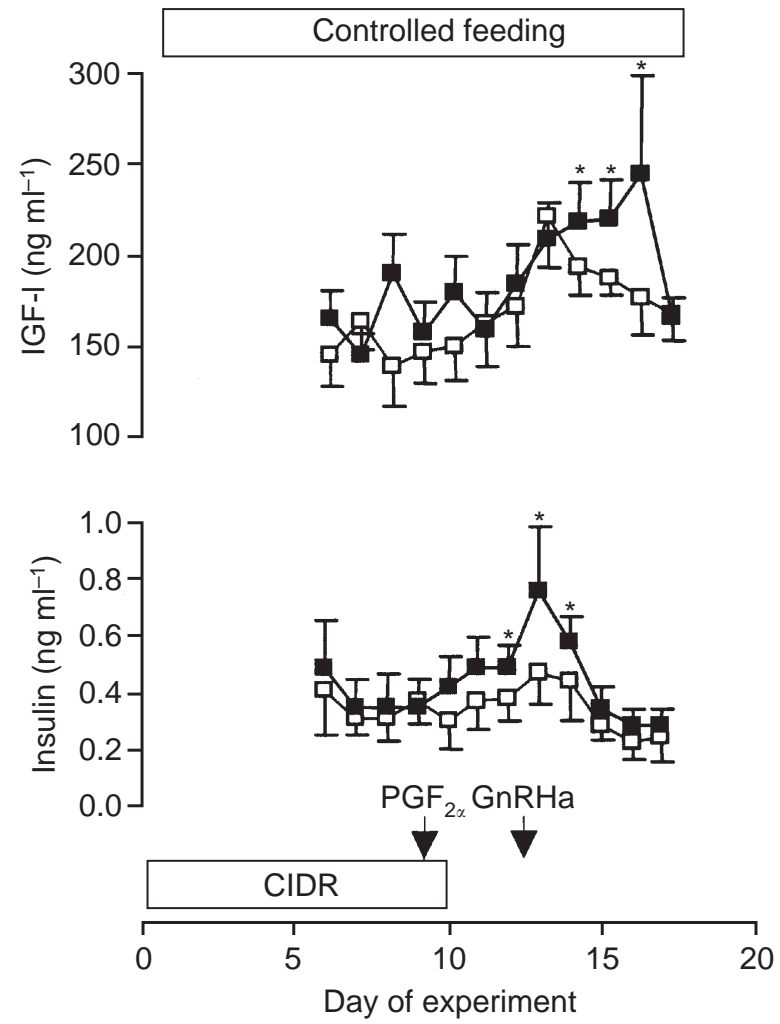

Fig. 1. Serum insulin and insulin-like growth factor I (IGF-I) concentrations during and after synchronization of oestrus in cattle offered maintenance $(\square)$ or twice maintenance $(\boldsymbol{\square})$ diets. PGF $2 \alpha$ and gonadotrophin-releasing hormone agonist $(\mathrm{GnRHa})$ treatments are shown. The periods of progesterone treatment (CIDR) and controlled feeding are also shown. Values are mean \pm SEM. *Indicates a significant difference between diets on that day $(P<0.05)$.

cultures (after correction for number of cells) with the corresponding pooled standard error of the difference.

\section{Results}

\section{Animal weights and body condition score}

There was no significant effect of diet on body condition score $(2.2 \pm 0.07)$ or body weight $(440.6 \pm 10.5 \mathrm{~kg})$ of the heifers throughout the 17 day period of controlled feeding.

\section{Follicle dynamics}

Within $24 \mathrm{~h}$ of $\mathrm{GnRH}$ treatment, 10 of 12 heifers fed the maintenance diet and nine of 12 heifers fed the twice maintenance diet had ovulated. The other heifers all ovulated within $48 \mathrm{~h}$ of the GnRH treatment. The diameter of the largest follicle on the day before death was $6.9 \pm 0.7 \mathrm{~mm}$ and $7.1 \pm 0.5 \mathrm{~mm}$ in heifers offered the maintenance and twice maintenance diets, respectively, and was not significantly different between the two groups. The diameter of the largest follicle on the day of $\mathrm{GnRH}$ treatment was $14.8 \pm 0.3 \mathrm{~mm}$ and $15.1 \pm 0.4 \mathrm{~mm}$ in cattle 

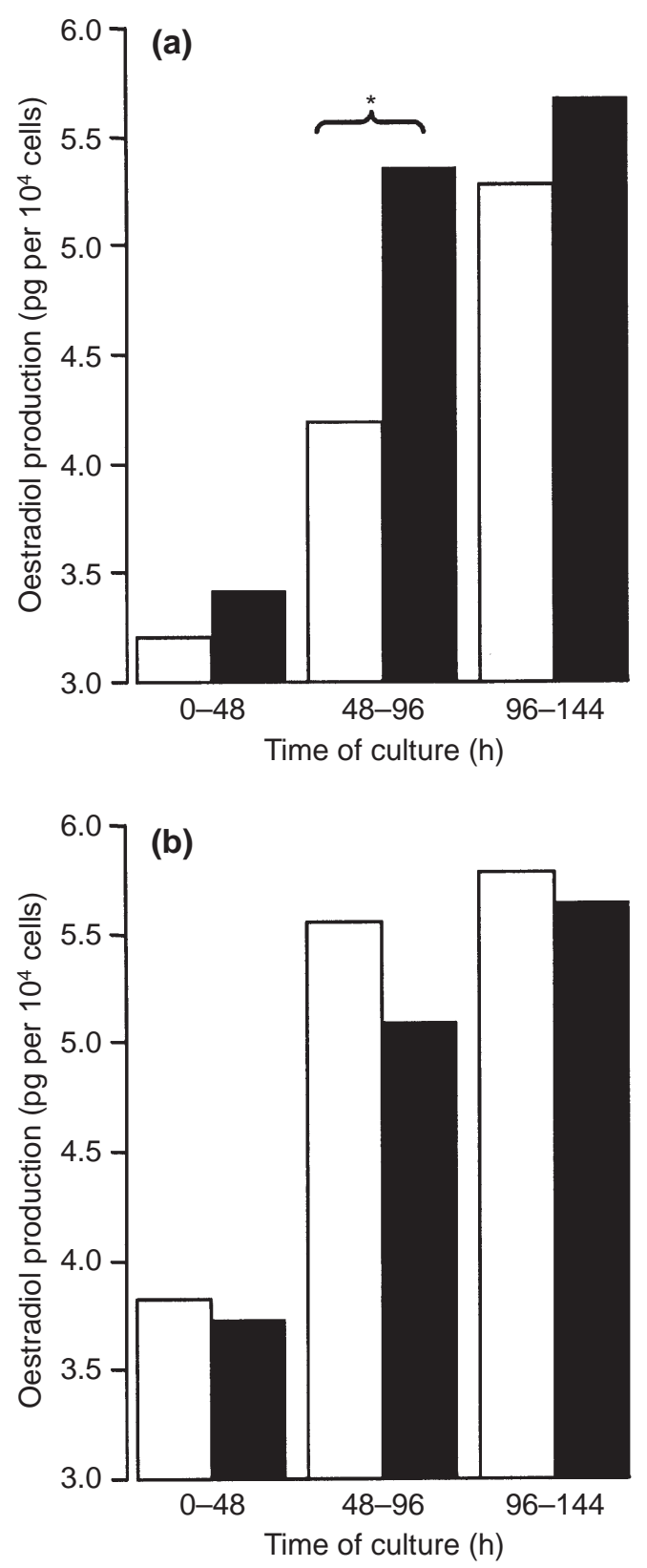

Fig. 2. Oestradiol production (shown on a natural logarithmic scale) by bovine granulosa cells during $0-48 \mathrm{~h}, 48-96 \mathrm{~h}$ and 96-144 h of culture. Granulosa cells were isolated from (a) small (1-4 mm) and (b) medium-sized (4-8 mm) ovarian follicles collected from heifers offered either maintenance $(\square)$ or twice maintenance $(\square)$ diets. Granulosa cells were cultured under serum-free conditions in the presence of $\mathrm{FSH}\left(0.1 \mathrm{ng} \mathrm{ml}^{-1}\right)$, insulin (10 $\mathrm{ng} \mathrm{m}^{-1}$ ) and long R3 insulin-like growth factor I (IGF-I; $10 \mathrm{ng} \mathrm{ml}^{-1}$ ). The results are means of three separate experiments with SED representing the pooled standard error of the difference. *Indicates a significant difference in oestradiol production between diets within follicle size and culture time $(P<0.05)$.

fed the maintenance and twice maintenance diets, respectively, and was not significantly different between the two groups.

On day 3 after $\mathrm{GnRH}$ treatment there was a significant
$(P<0.05)$ increase in the number of small $(1-4 \mathrm{~mm})$ follicles in heifers offered the twice maintenance diet $(n=12.3 \pm 2.3) \quad$ compared with heifers fed on the maintenance diet $(n=7.6 \pm 1.4)$. In contrast, there was no difference in the number of medium-sized $(5-8 \mathrm{~mm})$ follicles in heifers offered the twice maintenance $(n=7.1 \pm 0.5)$ and maintenance $(n=6.9 \pm 0.7)$ diets.

\section{Systemic hormones}

Changes in the circulating concentrations of insulin and IGF-I are shown (Fig. 1). The higher maintenance diet tended to increase insulin concentrations during the experimental period. There was a significant diet $X$ day interaction $(P<0.05)$ and the largest difference in insulin concentrations between the two diets was associated with the $\mathrm{GnRH}$-induced ovulation. There was a significant diet $X$ day interaction $(P<0.05)$ on IGF-I concentrations, with significant differences $(P<0.05)$ apparent on the 3 days after GnRH treatment only.

There was no effect of diet or diet $x$ day interaction on circulating $\mathrm{FSH}$ concentrations. The mean plasma FSH concentration throughout the experimental period was $0.49 \mathrm{ng} \mathrm{ml}^{-1}$ (data not shown).

\section{Number of cells}

Numbers of cells were estimated at the end (144 h) of culture. There was a tendency for $\mathrm{FSH}$ to increase the number of cells $(P=0.07)$; however, diet had no effect on number of cells. In addition, there were no significant interactions between diet, follicle size and $\mathrm{FSH}$, or diet, follicle size and LR3-IGF-I on the number of cells measured at the end of the culture period.

\section{Steroid production by granulosa cells}

Steroid production is shown as the amount of steroid produced during the $0-48 \mathrm{~h}, 48-96 \mathrm{~h}$ or $96-144 \mathrm{~h}$ period after adjusting for carryover of culture medium from the earlier time period. Steroid secretion during the first $0-48 \mathrm{~h}$ of culture was adjusted for number of cells using the number of viable cells plated at the start of the culture, and secretion during 48-96 h and 96-144 h of culture was adjusted for number of cells using cell counts assessed at the end of each culture period.

After an initial lag period of $48 \mathrm{~h}$, oestradiol production increased for up to $144 \mathrm{~h}$ in culture (Fig. 2). Oestradiol production by granulosa cells from small follicles collected from heifers offered a twice maintenance diet was significantly higher $(P<0.05)$ than in follicles collected from heifers offered a maintenance diet after 96 h, but not 144 h, of culture. This effect of diet on oestradiol production by granulosa cells from small follicles was not observed with granulosa cells isolated from medium-sized follicles.

The effect of FSH on oestradiol production by granulosa cells from small and medium-sized follicles after culture for 4 days is shown (Fig. 3). Diet had no effect on the sensitivity of granulosa cells towards FSH; however, granulosa cells 

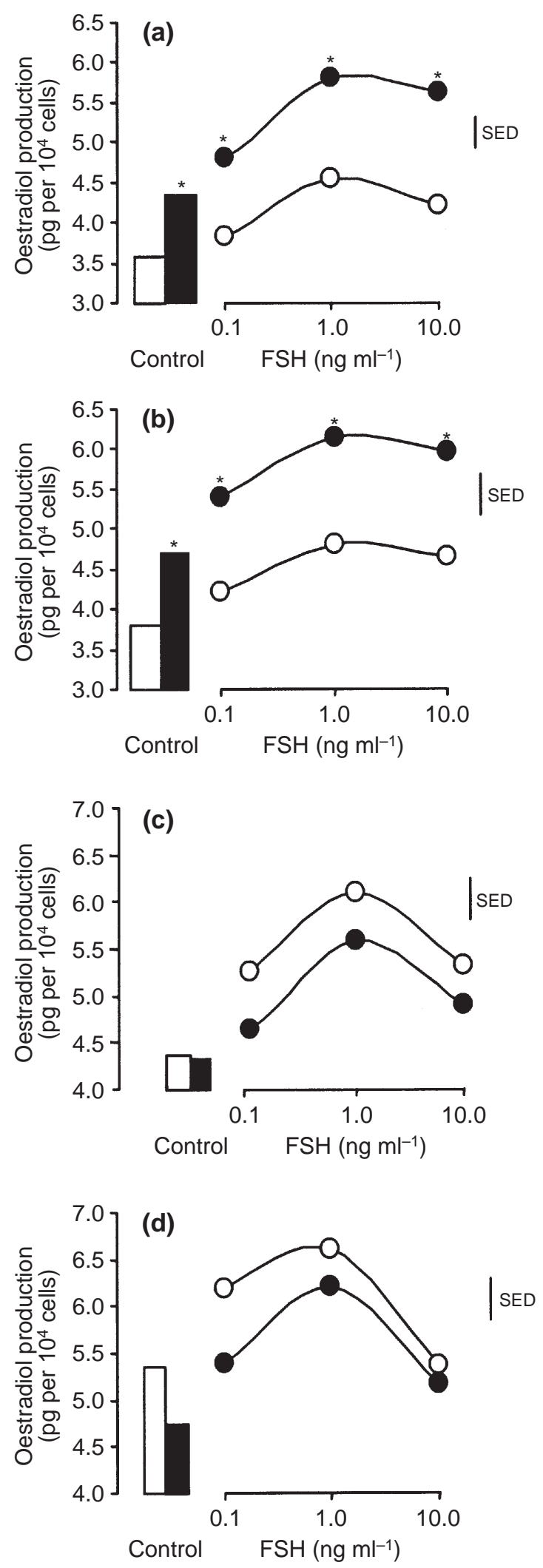

Fig. 3. The effect of FSH on oestradiol production (pg per $10^{4}$ cells; natural logarithmic scale) by bovine granulosa cells during 48-96 h of culture. Granulosa cells were isolated from $(a, b)$ small $(1-4 \mathrm{~mm})$ and $(\mathrm{c}, \mathrm{d})$ medium-sized $(4-8 \mathrm{~mm})$ follicles and were cultured from small follicles collected from heifers offered the twice maintenance diet produced 3.7-fold more oestradiol than did heifers offered the maintenance diet. This effect was independent of the presence of LR3-IGF-I in the culture medium. In contrast, diet had no effect on FSH-regulated oestradiol production by granulosa cells from mediumsized follicles. Cultures containing LR3-IGF-I (Fig. 3b,d) secreted more oestradiol than did corresponding cultures containing no LR3-IGF-I (Fig. 3a,c)

Progesterone production by granulosa cells was increased after $96 \mathrm{~h}$ of culture in the presence of $\mathrm{FSH}$ (10 $\mathrm{ng} \mathrm{m}^{-1}$ ). Unlike oestradiol production, there was no effect of diet on progesterone production by granulosa cells from either small or medium-sized follicles (Fig. 4). Cells cultured in the presence of LR3-IGF-I (Fig. 4b,d) secreted more progesterone than did corresponding cells cultured in the absence of LR3-IGF-I (Fig. 4a,c).

\section{Discussion}

The results described in the present study indicate that a change in dietary intake from one- to two-times maintenance increased circulating concentrations of insulin and IGF-I. This increase was associated with an increase in both the number of small follicles and the steroidogenic potential of granulosa cells from small but not medium-sized follicles. These data complement previous observations showing that short-term changes in dietary intake can change follicle dynamics in cattle (Gutierrez et al., 1997a; Armstrong et al., 2001; Gong et al., in press) without significant alterations in circulating $\mathrm{FSH}$ concentrations. These results, when combined with those of other studies that show a positive correlation between nutritionally (Beam and Butler, 1999) and hormonally (Gong et al., 1991, 1997) induced changes in metabolic hormones and follicular growth, provide further evidence for a role for insulin and IGF-I in regulation of follicle recruitment and granulosa cell differentiation in cattle. Reduced dietary intake also affects follicle development (Murphy et al., 1991), with the continued loss of body reserves resulting in nutritionally induced anoestrus (Richards et al., 1991). The reductions in the circulating concentrations of insulin and IGF-I associated with severe nutrient restriction are also believed to contribute directly to reduced follicular function (Bossis et al., 1999).

A study in which insulin was infused into cattle concomitantly with an FSH superovulatory regimen

under serum-free conditions with insulin $\left(10 \mathrm{ng} \mathrm{m}^{-1}\right)$ in the $(\mathrm{a}, \mathrm{c})$ absence and $(b, d)$ presence of long R3 insulin-like growth factor I (IGF-I; $10 \mathrm{ng} \mathrm{ml}^{-1}$ ). Granulosa cells were collected from heifers offered either maintenance $(\square, \bigcirc)$ or twice maintenance $(\boldsymbol{\square}, \mathbf{Q})$ diets. SED represents pooled standard error of the difference from three separate experiments. ${ }^{*}$ Indicates a significant difference in oestradiol production between diets within follicle sizes and IGF treatment $(P<0.05)$. The control represents oestradiol production by granulosa cells in the absence of FSH. 

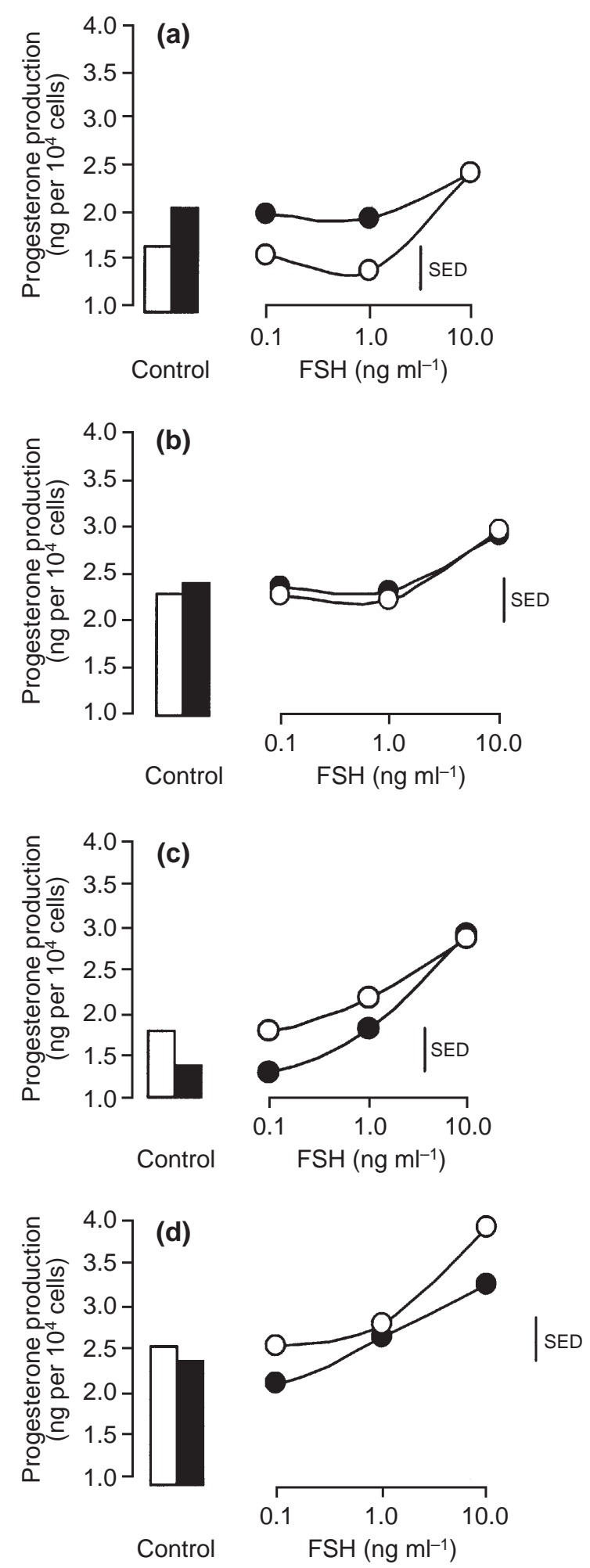

Fig. 4. The effect of FSH on progesterone production (shown on a natural logarithmic scale) by bovine granulosa cells during the 48-96 h of culture. Granulosa cells were isolated from $(a, b)$ small (1-4 mm) and (c,d) medium-sized (4-8 mm) follicles and were cultured under serum-free conditions with insulin $\left(10 \mathrm{ng} \mathrm{ml}^{-1}\right)$ in the $(\mathrm{a}, \mathrm{c})$ absence and $(\mathrm{b}, \mathrm{d})$ presence of long R3 insulin-like growth factor I (IGF-I; $10 \mathrm{ng} \mathrm{ml}^{-1}$ ). Granulosa cells were collected from
(Simpson et al., 1994) resulted in an increase in the diameter of the largest follicle; however, there was no effect of treatment on the number of small, medium or large follicles. This is in contrast to results presented in the present study and in our recent studies which showed that nutritionally induced changes in insulin concentrations increased both the number of small follicles (Gutierrez et al., 1997a; Gong et al., in press) and the superovulatory response (Gong et al., in press). The reasons for these differences are unclear; however, these results do indicate that, in addition to insulin, nutritionally induced changes in other metabolic hormones such as leptin and IGF-I, as well as metabolic fuels, are important in regulation of follicle development.

Significant increases in circulating concentrations of insulin and IGF-I were associated with the GnRH-induced ovulation. The effect was most pronounced in heifers offered the twice maintenance diet. Similar results were observed by Armstrong et al. (2001) and are probably associated with increasing oestradiol concentrations during the follicular phase of the cycle stimulating hepatic IGF-I production (Richards et al., 1991). Other studies have demonstrated a significant interaction between body condition score of heifers and stage of oestrous cycle on circulating insulin concentration, with maximum differences occurring during oestrus (McCann and Hansel, 1986).

The mechanisms by which these nutritionally induced changes in IGF-I and insulin alter follicle dynamics are still unclear. The follicular IGF system has been implicated in this process, with nutritionally- (Hamilton et al., 1999) and insulin- (Simpson et al., 1994) induced changes in the concentration of components of the IGF system in follicular fluid being recorded. More recently, a direct effect of diet on the expression of follicular IGFBP-2 and -4 was described (Armstrong et al., 2001). These changes in the IGF system are believed to alter the sensitivity or response of follicles to $\mathrm{FSH}$, thereby directly contributing to the observed changes in number of follicles and follicle size.

The results of the present study demonstrate that nutritionally induced changes in metabolic hormones directly affect oestradiol production in cultured granulosa cells from small follicles. In intact follicles, the production of oestradiol by granulosa cells is controlled by the supply of androgen precursors from thecal cells and regulation of aromatase activity by $\mathrm{FSH}$. As the granulosa cell cultures described in the present study contained testosterone, the changes in the amount of oestradiol produced by granulosa cells between cattle offered the maintenance and twice maintenance diets must be a result of changes in the amount or activity of aromatase activity. As discussed above, this is most likely to be the result of metabolic hormones directly affecting the follicular IGF system,

heifers offered either maintenance $(\square, \bigcirc)$ or twice maintenance $(\boldsymbol{\square}, \mathbf{O})$ diets. SED represents pooled standard error of the difference from three separate experiments. The control represents oestradiol production by granulosa cells in the absence of $\mathrm{FSH}$. 
which, in turn, increases the response of granulosa cells from small follicles to FSH.

An alternative explanation for the differences in oestradiol production by granulosa cells isolated from cattle offered the maintenance and twice maintenance diets is that they were due to dietary-induced differences in number of cells between the cultures during 48-96 h of culture. The design of the experiment was such that the number of cells at $96 \mathrm{~h}$ had to be estimated from the number of cells obtained after $144 \mathrm{~h}$ of culture. However, as there was no effect of diet on the number of cells counted after $144 \mathrm{~h}$, this alternative explanation is unlikely.

Increased nutrition has also been shown to decrease circulating concentrations of progesterone in ruminants, presumably by increasing its clearance rate (Boland et al., 2001; Rabiee et al., 2001). Therefore, it is possible that increased dietary intake can enhance steroidogenesis in granulosa cells through this mechanism. Decreased circulating progesterone concentration would be expected to increase the secretion of $\mathrm{LH}$, which, in turn, would stimulate androgen production by thecal tissue, which is then aromatized to oestrogens by granulosa cells. However, although increased feed intake consistently reduces peripheral concentrations of progesterone in sheep (see Boland et al., 2001), the results in cattle are more variable. Enhanced dietary intake has been shown to increase (McCann and Hansel, 1986; Dunn and Moss, 1992), decrease (Villa-Godoy et al., 1990) or have no effect (Spitzer et al., 1978) on circulating progesterone concentrations in heifers. Although plasma progesterone concentrations were not measured in the present study, the same dietary regimen (feeding with $200 \%$ maintenance diet) increased rather than decreased circulating concentrations of progesterone in the study of Gutierrez et al. (1997a).

Oestrogens are important regulators of ovarian function (Palter et al., 2001). Their effects on follicle growth are mediated primarily through oestrogen receptor beta and expression of this receptor has been detected in granulosa cells of bovine antral follicles at various stages of development (Rosenfeld et al., 1999). Although follicular concentrations of oestrogen were not measured in the present study, Simpson et al. (1994) demonstrated that the direct administration of insulin to heifers increased intrafollicular concentrations of oestrogens and it is likely that the dietary-induced increase in insulin described in the present study will have similar effects. Oestradiol is recognized as a follicle survival factor (Kaipia and Hsueh, 1997) and, therefore, the dietary-induced changes in steroidogenic potential of small follicles could be one mechanism through which short-term changes in dietary intake regulate follicle dynamics in cattle.

Increased oestradiol production by cultured granulosa cells from small follicles collected from cattle offered the twice maintenance diet was observed at day 4 of culture but was not observed at day 6 of culture. The increased oestradiol production is probably a result of dietary-induced changes in the follicular IGF system increasing the sensitivity of follicles to FSH. However, it is not clear why this effect disappears after day 6 of culture. When granulosa cells are removed from the follicle, it would be expected that any dietary-induced differences in intrafollicular IGF bioavailability in small follicles would be lost. The results presented in the present study indicate that it takes about 6 days of culture for this effect to be manifested. This conclusion is supported by a previous study (Gutierrez, 1997) in which it was shown that bovine granulosa cells maintained their in vivo characteristics early in culture and that this was progressively lost the longer the cells were maintained in culture.

In conclusion, the results of the present study support the hypothesis that dietary-induced changes in circulating insulin and IGF-I have a direct effect on the steroidogenic potential of bovine granulosa cells from small follicles. It is hypothesized that these effects are mediated by the intrafollicular IGF system and that increased oestradiol production, combined with the changes in the follicular IGF system in small follicles, is one mechanism through which short-term changes in dietary intake regulate follicle dynamics in bovine ovaries.

DEFRA (contract DS0206) and the BBSRC supported this work.

\section{References}

AFRC (1993) Energy and Protein Requirements of Ruminants: an Advisory Manual Prepared by the AFRC Technical Committee on Reponses to Nutrients CAB International, Surrey

Armstrong DG, Duclos MJ and Goddard C (1990) C biological activity of insulin-like growth factor-I purified from chicken serum Domestic Animal Endocrinology 7 383-393

Armstrong DG, McEvoy TG, Baxter G, Robinson JJ, Hogg CO, Woad KJ and Webb R (2001) Effect of dietary energy and protein on bovine follicular dynamics and embryo production in vitro: associations with the ovarian insulin-like growth factor system Biology of Reproduction 64 1624-1632

Beam SW and Butler WR (1999) Effects of energy balance on follicular development and first ovulation in postpartum dairy cows Journal of Reproduction and Fertility Supplement 54 411-424

Boland MP, Lonergan P and $\mathbf{O}^{\prime}$ Callaghan D (2001) Effect of nutrition on endocrine parameters, ovarian physiology, and oocyte and embryo development Theriogenology 55 1323-1340

Bossis I, Wettemann RP, Welty SD, Vizcarra Spicer LJ and Diskin MG (1999) Nutritionally induced anovulation in beef heifers: ovarian and endocrine function preceding cessation of ovulation Journal of Animal Science 77 1536-1546

Campbell BK, Scaramuzzi RJ and Webb R (1996) Induction and maintenance of oestradiol and immunoreactive inhibin production with FSH by ovine granulosa cells cultured in serum free media Journal of Reproduction and Fertility 106 7-16

Corrie J, Hunter W and Macpherson J (1981) A strategy for radioimmunoassay of plasma progesterone with the use of homologous site 125I-labelled radioligand Clinical Chemistry 27 594-599

Dunn TG and Moss GE (1992) Effects of nutrient deficiencies and excesses on reproductive efficiency of livestock Journal of Animal Science $\mathbf{7 0}$ 1580-1593

Glister C, Tannetta DS, Groome NP and Knight P (2001) Interactions between follicle-stimulating hormone and growth factors in modulating secretion of steroids and inhibin-related peptides by nonluteinized bovine granulosa cells Biology of Reproduction 65 1020-1028

Gong JG, Bramley TA and Webb R (1991) The effect of recombinant bovine 
somatotropin on ovarian function in heifers: follicular populations and peripheral hormones Biology of Reproduction 45 941-949

Gong JG, Bramley TA and Webb R (1993) The effect of recombinant bovine somatotrophin on ovarian follicular growth and development in heifers Journal of Reproduction and Fertility 97 247-254

Gong JG, McBride D, Bramley TA and Webb R (1994) Effects of recombinant bovine somatotrophin, insulin-like growth factor-I and insulin on bovine granulosa cell steroidogenesis in vitro. Journal of Endocrinology 143 157-164

Gong JG, Bramley TA, Gutierrez CG, Peters AR and Webb R (1995) Effects of chronic treatment with a gonadotrophin-releasing hormone agonist on peripheral concentrations of $\mathrm{FSH}$ and $\mathrm{LH}$, and ovulation function in heifers Journal of Reproduction and Fertility 105 263-270

Gong JG, Baxter G, Bramley TA and Webb R (1997) Enhancement of ovarian follicular development in heifers by treatment with recombinant bovine somatotropin: a dose-response study Journal of Reproduction and Fertility $11091-97$

Gong JG, Armstrong DG, Baxter G, Hogg CO, Garnsworthy PC and Webb $\mathbf{R}$ The effect of increased dietary intake on superovulatory response to FSH in heifers Theriogenology (in press)

Gutierrez CG (1997) The Effect of Nutrition and Metabolic Hormones on Follicular Development in Cattle PhD Thesis, University of Edinburgh

Gutierrez CG, Oldham J, Bramley TA, Gong JG, Campbell BK and Webb R (1997a) The recruitment of ovarian follicles is enhanced by increased dietary intake in heifers Journal of Animal Science 75 1876-1884

Gutierrez CG, Campbell BK and Webb R (1997b) Development of a long-term bovine granulosa cell culture system: induction and maintenance of oestradiol production, response to follicle stimulating hormone and morphological characteristics Biology of Reproduction $\mathbf{5 6}$ 608-616

Gutierrez CG, Campbell BK, Armstrong DG and Webb R (1997c) Insulinlike growth factor-I (IGF-I) production by bovine granulosa cells in vitro and peripheral IGF-I measurement in cattle serum: an evaluation of IGFBP extraction protocols Journal of Endocrinology 153 231-240

Hamilton TD, Vizcarra JA, Wettemann RP, Keefer BE and Spicer LJ (1999) Ovarian function in nutritionally induced anoestrous cows: effect of exogenous gonadotrophin releasing hormone in vivo and effect of insulin and insulin-like growth factor I in vitro. Journal of Reproduction and Fertility 117 179-187

Holtorf AP, Furuya K, Ivell R and McAndle CA (1989) Oxytocin production and oxytocin messenger ribonucleic acid levels in bovine granulosa cells are regulated by insulin and insulin-like growth factor-l: dependence on developmental status of the ovarian follicle Endocrinology 125 2612-2620

Kaipia A and Hsueh JW (1997) Regulation of ovarian follicle atresia Annual Reviews of Physiology 59 349-363

McCann JP and Hansel W (1986) Relationship between insulin and glucose metabolism and pituitary-ovarian functions in fasted heifers Biology of Reproduction 34 630-641

Murphy MG, Enright WG, Crowe MA, McConnell K, Spicer LJ, Boland MP and Roche JF (1991) Effect of dietary intake on pattern of growth of dominant follicles during the oestrous cycle of beef heifers Journal of Reproduction and Fertility 92 333-338
O'Callaghan D and Boland MP (1999) Nutritional effects on ovulation, embryo development and the establishment of pregnancy in ruminants Animal Science 68 299-314

Palter SF, Tavares AB, Hourvitz A, Veldhuis JD and Adashi EY (2001) Are estrogens of importance to primate/human ovarian folliculogenesis? Endocrine Reviews 22 389-424

Rabiee AR, Macmillan KL and Schwarzenberger F (2001) Progesterone metabolism in ovariectomised non-lactating Holstein-Friesian cows treated with progesterone with two levels of feed intake Animal Reproduction Science 66 35-46

Rhodes FM, Fitzpatrick LA, Entwistle KW and De'ath G (1995) Sequential changes in ovarian follicular dynamics in Bos indicus heifers before and after nutritional anoestrus Journal of Reproduction and Fertility 104 41-49

Richards MW, Welleman RP, Spicer LJ and Morgan CL (1991) Nutritional anestrous in beef cows: effect of body condition and overiectomy on serum luteinizing hormone and insulin-like growth factor-I Biology of Reproduction 44 961-966

Robinson JJ (1990) Nutrition in the reproduction of farm animals Nutrition Research Reviews 3 253-276

Robinson JJ, Sinclair KD and McEvoy TG (1999) Nutritional effects on foetal growth Animal Science 68 315-332

Rosenfeld CS, Yuan X, Manikkam M, Calder MD, Gaverick HA and Lubahn DB (1999) Cloning, sequencing, and localization of bovine estrogen receptor- $\beta$ within the ovarian follicle Biology of Reproduction $\mathbf{6 0}$ 691-697

Simpson RB, Chase CC, Jr, Spicer LJ, Vernan RK, Hammond AL and Rae DO (1994) Effects of exogenous insulin on plasma and follicular insulinlike growth factor I, insulin-like growth factor binding activity, follicular oestradiol and progesterone and follicular growth in superovulated Angus and Brahman cows Journal of Reproduction and Fertility 102 483-492

Sinclair KD, Kuran M, Gebbie FE, Webb R and McEvoy TG (2000) Nitrogen metabolism and fertility in cattle: II. Development of oocytes recovered from heifers offered diets differing in their rate of nitrogen release in the rumen Journal of Animal Science 78 2670-2689

Spitzer JC, Niswender GD, Seidel GE and Wiltbank JN (1978) Fertilization and blood levels of progesterone and $\mathrm{LH}$ in beef heifers on a restricted energy diet Journal of Animal Science 46 1071-1077

Villa-Godoy A, Hughes TL, Emery RS, Enright WJ, Ealy AD, Zinn SA and Fogwell RL (1990) Energy balance and body condition influence on luteal function in Holstein heifers Domestic Animal Endocrinology 7 135-148

Webb R, Baxter G, McBride D, Nordblom C and Shaw M (1985) The measurement of testosterone and oestradiol-17 $\beta$ using iodinated tracers and incorporating an affinity chromatography extraction procedure Journal of Steroid Biochemistry 23 1043-1051

Received 13 August 2001.

First decision 8 October 2001.

Accepted 22 November 2001. 